\title{
The Sexual Policies and Sexual
}

\section{Realities of the German}

\section{Occupiers in Poland in the}

\section{Second World War}

\author{
MAREN R Ö GER
}

\begin{abstract}
Sexual policies were a core component of the National Socialist racial policies, both in the Altreich (territories considered part of Nazi Germany before 1938), as well as in the occupied territories. In occupied Poland the Germans imposed a 'prohibition of contact' (Umgangsverbot) with the local Polish population, a restriction that covered both social as well as sexual encounters. But this model of absolute racial segregation was never truly implemented. This paper attempts to show that there existed a wide range of sexual contacts between the occupiers and the local inhabitants, with the focus here being on consensual and forced contacts (sexual violence) as seen against the backdrop of National Socialist policies. This article positions itself at the intersection of the history of everyday life (Alltagsgeschichte), the history of sexuality and the gender history of the German occupation of Poland - perspectives that have rarely been used with regard to this region.
\end{abstract}

\section{Introduction}

The invasion of Poland in September 1939 was the beginning of a brutal occupation. Out of 35 million pre-war citizens, between five to six million perished. In addition to this, millions of people were physically and psychologically harmed by the German occupiers. Forced labour and mass deportations affected large parts of Polish society and for the overwhelming majority of the Polish population both the awareness of and the reality of being deprived of their rights led to a deep feeling of uncertainty.

To organise and carry out their murderous and racist policies, around one million Germans were stationed for shorter or longer periods in the occupied territories of

German Historical Institute Warsaw, Aleje Ujazdowskie 39, PL oo-540, Warsaw, Poland; roeger@, dhi.waw.pl

The author would like to thank the anonymous reviewers for their helpful comments on earlier drafts of this paper.

Contemporary European History, 23, I (2014), pp. I-2I. (C) Cambridge University Press 2013

doi:10.1017/S0960777313000490 
Poland. ${ }^{1}$ According to the ideology of the Nazi occupiers, the newly created Polish territories were to be strictly segregated along racist lines. German occupiers from the Nazi empire (Reich) would rule, supported by the newly created intermediate social strata of 'ethnic Germans' (Volksdeutsche) and Ukrainians. Below them the German model placed the Poles, who would serve mainly as a labour force. At the bottom of this hierarchy were the Polish Jews. Beyond inevitable administrative interactions, the Germans during the occupation were to have no further contact with the Polish locals, who were classified in the National Socialist racial scheme as 'sub-humans'. Because of the idea of a Volkskörper [German national body], which had to be kept free of foreign influences, the Umgangsverbot [prohibition of contact] was aimed especially at sexual intercourse. ${ }^{2}$

Yet this plan of absolute racial segregation was never put into practice. This paper seeks to show that a wide range of sexual contact existed between the occupiers and the people in the occupied Polish territories. Generally speaking, three different kinds of contact can be distinguished: firstly, commercial contact in organised brothels and with monitored prostitutes. Secondly, consensual contact meaning all forms of consensual relations between the occupiers and the local inhabitants. Thirdly, forced contact, meaning all forms of sexual violence inflicted by the Germans. ${ }^{3}$ The main areas addressed in this article are consensual and forced contacts against the background of the occupiers' policies, while the issue of brothels set up by the occupiers is only briefly mentioned.

One of the main aims of this article is to provide documentation of both the violent and the consensual encounters in occupied Poland, which - until now have been considered by historians only to a limited extent. Four main hypotheses are presented: firstly, that during the whole period of the occupation there was a divergence between sexual policy (prohibition) and sexual reality. Secondly, I contend that that the occupying authorities were aware of this, and reacted with a range of responses, from allowing some leeway to imposing severe punishments. This range applied to both forced contact and consensual contact. Thirdly, regarding consensual contact, I maintain that the first period of the occupation has to be differentiated from the later years. In the very beginning, contact between Polish women and German men was not uncommon. Fourthly, it is suggested that the sexual behaviour of some German men clearly mirrored their internalisation of the idea of being Herrenmenschen in the occupied East. They blackmailed, molested, and raped local women, surely

1 See Czesław Madajczyk, Die Okkupationspolitik Nazideutschlands in Polen 1939-1945 (Berlin: AkademieVerlag, 1987), 239-40: because of the continuous fluctuations, the given numbers are to be understood as approximations.

2 For the most substantial discussion on the prohibition of contact see Silke Schneider, Verbotener Umgang: Ausländer und Deutsche im Nationalsozialismus: Diskurse um Sexualität, Moral, Wissen und Strafe (BadenBaden: Nomos, 20I0).

3 The chapter is part of a research project that I began in 2010 at the German Historical Institute in Warsaw that includes these three dimensions. See my forthcoming monograph Sexual Policies and Sexual Realities in German Occupied Poland: Prostitution, Fraternization, Sexual Violence. 
aware that Polish statements would be easily doubted if they came before the courts, but they also used booty to attract Polish women, offering them material goods.

Before turning to the existing literature, a brief review of the complicated situation in occupied Poland would be appropriate: on I September I939 Germany invaded Poland. On I7 September I939, the Soviet Union attacked the eastern territories of Poland in accordance with the secret protocols of the Molotov-Ribbentrop Pact. By the end of September 1939, conquered Poland had been divided between the Soviet and the German occupiers. The western part of German-occupied Poland had about ten million inhabitants and was incorporated into the German Reich, but not granted the same legal status. The remaining part of Poland conquered by Germany became the Generalgouvernement or General Government (GG) for the Occupied Polish Territories. German occupation policies were brutal in both territories, although there were differences. With the attack on the Soviet Union in I94I, Germany added to the GG some of the territories of eastern Poland previously occupied by the Soviet Union, increasing the GG to about twelve million inhabitants. In I944, Soviet troops once again entered Polish territory to liberate the country. This liberation was perceived by many Poles as another invasion because it set the stage for communist Poland.

For a long time the methods used in military and administrative history have dominated research about German-occupied Poland, focusing on the violent history of the occupation, on the horror and the mechanisms of the Holocaust, and the responsibility for crimes against non-Jewish Poles. ${ }^{4}$ One criticism about much of this literature is that it has failed to integrate sexual violence in occupied Poland into the patterns of violence that the Germans employed. Only in recent years - besides one important Polish study published as early as $1973^{5}$ - has the subject been approached from the perspectives of the 'history of experience' (Erfahrungsgeschichte) and the 'history of everyday life' (Alltagsgeschichte), in order to explore daily lives of the people in occupied Poland and the occupier. In doing so, these efforts focused on either one or the other group and to a large extent tracked the real-life separation of the German occupiers and the Poles suffering under the occupation. ${ }^{6}$ Recently,

4 The literature on the German occupation of Poland is extensive and cannot be cited here. The greater part of the relevant literature is in German and Polish. For an English language introduction about one part of occupied Poland, see Jan Tomasz Gross, Polish Society Under German Occupation: The General Governement, 1939-1944 (Princeton, NJ: Princeton University Press I979).

${ }^{5}$ For the early study on the everyday history of Warsaw inhabitants, see Tomasz Szarota, Okupowanej Warszawy dzień powszedni: Studium historyczne (Warsaw: Czytelnik, I973).

${ }^{6}$ For the history of everyday life in occupied Cracow see Anna Czocher, $W$ okupowanym Krakowie: Codzienność polskich mieszkańców miasta 1939-1945 (Gdańsk: Oskar, 20II); for Warsaw see new edn of Tomasz Szarota, Okupowanej Warszawy Dzien Powszedni: Studium Historyczne, 4th edn (Warsaw: Czytelnik, 20Io). Concerning the occupiers see Elizabeth Harvey, Women and the Nazi East: Agents and Witnesses of Germanization (New Haven, Conn.: Yale University Press, 2003), Stefan Lehr, Ein fast vergessener 'Osteinsatz': Deutsche Archivare im Generalgouvernement und im Reichskommissariat Ukraine (Dusseldorf: Droste, 2007), and Markus Roth, Herrenmenschen: Die deutschen Kreishauptleute im besetzten Polen - Karrierewege, Herrschaftspraxis und Nachgeschichte (Göttingen: Wallstein, 2009) with a focus on specific groups of occupiers and their understanding of roles and experiences. For a view on the 
however, some initial contributions have appeared addressing the issue of intimate relationships between Germans and Poles. ${ }^{7}$

The growing awareness of these questions is inter alia an effect of the successful introduction of the history of sexuality into the study of National Socialism. ${ }^{8}$ In the beginning, this research concentrated on the sexual policies of National Socialist authorities in the Altreich towards the part of the German population that was constructed as the Volksgemeinschaft, in other words the part of the population constructed as 'Aryan'. But research soon expanded to integrate the victims of the Germans. One strand of research focused on sexual violence, especially in the context of the extermination of the European Jewry. ${ }^{9}$ This body of literature is still growing. ${ }^{10}$ Most recently, sexual violence against non-Jews and Jews besides that in the ghettos and camps has become a relevant topic of research. ${ }^{11}$

The other strand of research arose from a slightly different background. In the I990s, journalists and filmmakers started to discover consensual relationships of German soldiers and local women during the Second World War, with the results

occupiers' life in Warsaw see Stephan Lehnstaedt, Okkupation im Osten: Besatzeralltag in Warschau und Minsk 1939-1944 (Munich: Oldenbourg, 2010).

${ }^{7}$ Peripherally, earlier studies made brief references to sexual contacts between the occupiers and the people of occupied Poland. Nevertheless it is only in more recent times that the first articles and chapters in books have appeared about what happened in the relationships between Germans and Poles. See Birthe Kundrus, 'Regime der Differenz: Volkstumspolitische Inklusionen und Exklusionen im Warthegau und im Generalgouvernement 1939-1944', in Frank Bajohr and Michael Wildt, eds, Volksgemeinschaft: Neue Forschungen zur Gesellschaft des Nationalsozialismus (Frankfurt am Main: Fischer, 2009), I05-23, Maren Röger, 'Sexual Contact between German Occupiers and Polish Occupied in World War II Poland', in Maren Röger and Ruth Leiserowitz, eds, Women and Men at War - A Gender Perspective on World War II and its Aftermath in Central and Eastern Europe (Osnabrück: fibre-Verlag, 20I2), I35-54. For Warsaw examples, see also Lehnstaedt, Okkupation, ch. IV.4, 'Sexualität zwischen Heirat und Rassenschande', 232-44.

${ }^{8}$ For an introduction in the field see the revealing essay by Elizabeth D. Heineman, 'Sexuality and Nazism: The Doubly Unspeakable?', Journal of the History of Sexuality, II, I/2 (2002), 22-66.

${ }^{9}$ See for an introduction to the debates and research fields Doris L. Bergen, 'Sexual Violence in the Holocaust: Unique and Typical', in Dagmar Herzog, ed., Lessons and Legacies VII: The Holocaust in International Perspective (Evanston, Ill.: Northwestern University Press, 2006), 179-200.

${ }^{10}$ One of the most recent contributions was an anthology, widely and critically discussed: Sonja M. Hedgepeth and Rochelle G. Saidel, eds, Sexual Violence Against Jewish Women during the Holocaust (Hanover, NH.: University Press of New England, 20Io).

${ }^{11}$ See Birgit Beck, Wehrmacht und sexuelle Gewalt: Sexualverbrechen vor deutschen Militärgerichten; 1939 - 1945 (Paderborn: Schöningh, 2004) for legal aspects. With a similar focus and almost no added value see David R. Snyder, Sex Crimes under the Wehrmacht (Lincoln, Nebr.: University of Nebraska Press, 2007). For the jurisdiction about cases of sexual violence in Warthegau see Monika Flaschka, Race, Rape and Gender in Nazi-Occupied Territories, Kent State University, 2009, https://etd.ohiolink.edu/ap:Io:o:: NO:Io:PIO_ACCESSION_NUM:kentI258726022 (accessed 2 Oct. 20I3). See with a focus on acts of violence in Ukraine, with some methodological shortcomings, GertjejanssenWendy J. Snyder, Victims, Heroes, Survivors: Sexual Violence on the Eastern Front During World War II, University of Minnesota, 2004, http://www.victimsheroessurvivors.info/VictimsHeroesSurvivors.pdf (last visited I4 Sept. 2009), and with a focus on the war against Soviet union Regina Mühlhäuser, Eroberungen: Sexuelle Gewalttaten und intime Beziehungen deutscher Soldaten in der Sowjetunion, 1941-1945 (Hamburg: Hamburger Edition, 20IO), who integrates not only violent encounters but also consensual ones. 
being 'children born of war'. ${ }^{12}$ One serious weakness with these approaches, however, is that they tended to idealise the intimate contacts. One example is Hartmut Kaminski's title for the documentary film about sexual contact between German occupiers and Soviet Russian women: 'Love During the War of Extermination'. ${ }^{3}$ The historian Regina Mühlhäuser, by contrast, argues against a romanticised notion of sexual relations in the German-occupied Soviet Union. Instead she draws attention to how the occupation created a space dominated by hierarchical power relationships which were completely controlled by the occupiers. It was in this space that all forms of sexual encounters took place. ${ }^{14}$

Writing a history of occupied Poland focusing on the sexual policies and sexual realities of the occupiers is challenging, not least with regard to the source materials that can be used. Sexual behaviour is one of the most private activities, so we lack detailed written personal documents, such as letters and diaries. Unpleasant aspects are often filtered out in post-war remembrance literature and the same is generally true for oral-history interviews undertaken decades after the events happened. This is especially the case for experiences of sexual violence. Diverse oral-history studies dealing with sexual violence in wartime point out that victims of sexual violence tend to 'transfer' the experiences in their narrations onto neighbours, relatives, or acquaintances. ${ }^{15}$ But recollections of consensual relations were also kept out of remembrance literature. In most European countries, it was neither politically nor socially acceptable after 1945 to remember having had positive feelings towards any German occupier. Especially in Poland, which after the war had a strict censorship of historical writings and an anti-West German policy, positive or even intimate wartime encounters were not reported by the persons directly affected. Yet the phenomenon of fraternisation was described by those who had observed it. It was really only after 1989 that writing and speaking about this aspect of everyday life during the occupation became less inhibited. ${ }^{16}$ Violence and fraternisation were marginal issues in the occupiers' memories as well. Here the political context was not decisive, but rather the social one. Many of the soldiers who had engaged in sexual relationships had been married during the war, so publication of these stories would have been inconvenient for them. But another form of personal document turned out to be fruitful: letters from soldiers deployed in Poland. They provide a subjective view and

\footnotetext{
${ }^{12}$ See for this notion Ingvill C. Mochmann, Sabine Lee, and Barbara Stelzl-Marx, 'The Children of the Occupation Born During the Second World War and Beyond - An Overview', Historical Social Research/ Historische Sozialforschung, 34, 3 (2009), 263-8I. For a popular German account see Ebba D. Drolshagen, Nicht ungeschoren davonkommen: Die Geliebten der Wehrmachtssoldaten im besetzten Europa (Munich: Econ-Ullstein-List, 2000).

${ }^{13}$ See Hartmut Kaminski, Liebe im Vernichtungskrieg, BRD I999/2000.

${ }^{14}$ See Mühlhäuser, Eroberungen.

${ }^{15}$ See Marlene Epp, 'The Memory of Violence: Soviet and East European Mennonite Refugees and Rape in the Second World War', Journal of Women's History, 9, I (I997), 58-87, here 65.

${ }^{16}$ In 2010 and 20II, I conducted two dozen interviews in Poland, mainly with 'children born of war' who told me the story of their parents and their own experiences after 1945. These interviews are, however, not used in this essay.
} 
a contemporaneous (and often critical) perspective on the sexual behaviour of the German military and paramilitary forces.

The limitations on the quantity and quality of the personal written materials have resulted in a shifting of attention to the materials produced by the contemporaneous authorities, turning primarily the police and the court records of violations into a main source. This is true for sexual violence as well as for transgressions against the Umgangsverbot (prohibition of contact). ${ }^{17}$ National Socialist thinking significantly influenced these police reports and court verdicts. In addition to that, cultural assumptions about appropriate gender behaviour also strongly influenced the official investigations, which is made clear when ideas about the sexual needs and (sexual) rights and obligations of women and men find expression in the reports. The police reports and court decisions about sexual violence that are available are shaped by a formulaic language which in itself carries cultural concepts of gender relations, for example, men use or abuse women (brauchen/gebrauchen), take women (Frauen vornehmen), commit rape because of sexual needs (Triebverbrechen). While the first phrases show that women were viewed as objects, in the idea of Triebverbrechen one finds allowance for the sexual desire of the man becoming so strong that it led to the crime. In referring to these materials of the police and the courts, one should not assume automatically that they represent an objective account, but rather the occupiers' views about cases of fraternisation and sexual violence.

Many researchers in the field of sexual violence during wartime proceed on the assumption that the number of unreported cases is quite high. ${ }^{18}$ Even in times of peace, instances of abuse are only reported to a limited degree. The most frequent reasons for complaints not being made to the police are likely to have been shame and the desire to avoid the subsequent and often unpleasant investigative procedures and questioning. In times of foreign occupation generally, the number of unreported cases is higher especially when abuses against the local inhabitants needed to be reported. For occupied Poland, one should likewise assume a higher number of unreported cases. ${ }^{19}$ The confidence in the occupation authorities in Poland was low, because the occupiers' 'law' imposed very harsh punishments on Poles for even minor offences. ${ }^{20}$ In the surviving police and court files of occupied Poland there is not only clear evidence that many offences were not reported, but also that those offences which were prosecuted had often been reported merely by chance, for example, when a third party reported an offence to a trusted person among the occupiers.

\footnotetext{
${ }^{17}$ I prefer the notion of Umgangsverbot to that of Rassenschande [Racial Defilement]. Rassenschande referred to Jewish-Aryan contacts.

${ }^{18}$ See Beck, Wehrmacht und sexuelle Gewalt, 329.

${ }^{19}$ For this assumption for Poland see Roth, Herrenmenschen, 37.

${ }^{20}$ For the judicial system and practice, see Martin Broszat, 'Strafjustiz und Polensonderstrafrecht' in Nationalsozialistische Polenpolitik 1939-1945 (Stuttgart: Deutsche Verlagsanstalt, I96I); Diemut Majer, 'Fremdvölkische' im Dritten Reich: Ein Beitrag zur nationalsozialistischen Rechtssetzung und Rechtspraxis in Verwaltung und Justiz unter besonderer Berücksichtigung der eingegliederten Ostgebiete und des Generalgouvernements (Boppard am Rhein: Boldt, I98I); Andrzej Wrzyszcz, Okupacyjne sadownictwo niemieckie w Generalnym Gubernatorstwie 1939-1945: Organizacja i funkcjonowanie (Lublin: Wydawnictwo Uniwersytetu Marii Curie-Sklodowskiej, 2008).
} 


\section{The invasion}

Once the transfer of power (Machtübertragung) had taken place in Germany in I933, the Nazi party (Nationalsozialistische Deutsche Arbeiterpartei, NSDAP) took numerous steps to attain its ideal of a racially pure Germany. The Nuremberg laws of I935, which banned marriage and also sexual intercourse between Jewish Germans and non-Jewish Germans, were a significant step in this direction. The systematic persecution of couples who transgressed the laws banning sexual intercourse between Jews and non-Jews brought a progressive limiting of spaces where there could be 'racially mixed' contact in the Reich. ${ }^{21}$ However, for Germans the attack on Poland opened new meeting places with a non-German population. About I.5 million men $^{22}$ marched into a country that had a population of which two-thirds were Polish-speaking and Christian, with the rest being Jewish, Ukrainian, and German minorities. In Nazi racial thought, non-Jewish Poles were very low in the hierarchy since Slavs were classified as sub-humans. Accordingly, the Nazi authorities issued regulations regarding intimate contacts with the local residents. For members of the SS (Schutzstaffel) and police, Heinrich Himmler as Reichsführer-SS issued a decree on I9 April I939, that is after the annexation of Czechoslovakia but before the invasion of Poland. It said that sexual intercourse with women of a different race in the East was prohibited. Any transgressions were to be reported to him personally. ${ }^{23}$ Heinrich B., a member of Einsatzkommando II, reported after the war how they were informed about the 'prohibition of contact'. His unit, which crossed the Polish border from the Slovakian side, received on 23 August 1939 the following instructions: they should behave well in the host country, they were allowed to buy goods from Jewish stores, but not allowed to have sexual intercourse with the locals. It was only permissible to have that with ethnic Germans. ${ }^{24}$ This prohibition of intimate contact with Polish girls was also in effect for Wehrmacht personnel. ${ }^{25}$

While consensual contacts with Polish locals were forbidden for racial reasons, sexual violence was forbidden so as not to undermine military discipline. A brochure to be used for soldiers' education (printed only in I94I) reminded the soldiers of the 'new' National Socialist ideal:

In a hundred folk songs, soldiers have been told that they have a right to 'a pretty, a fine maid'. This claim has been expanded on in a thousand vulgar songs. These texts are not just old, they

${ }^{21}$ See Przyrembel Alexandra, 'Rassenschande': Reinheitsmythos und Vernichtungslegitimation im Nationalsozialismus(Göttingen: Vandenhoeck and Ruprecht, 200I; citations from 2003 edn).

${ }^{22}$ For numbers see Jochen Böhler, Auftakt zum Vernichtungskrieg: Die Wehrmacht in Polen 1939 (Frankfurt am Main: Fischer Taschenbuch, 2006), 33.

${ }^{23}$ See Bundesarchiv Berlin (hereafter BArch B): NS I9/3872, p. 27, repetition of the decree from I9.04.I939 in: Reichsführer-SS, Hauptamt SS-Gericht from 9.I2.I942: Sexual intercourse with women of 'alien nationality' (fremdvölkisch).

${ }^{24}$ See BArch B I62/I495, p. 678; report: Heinrich B., 'Mein Einsatz in Polen I7.8.1939-I9I3.2.I940 als SS-Oberscharführer Einsatzkommando II-Wien', written in Nov. I964 in penal institution Butzbach/ Hessen, p. 3 .

${ }^{25}$ From 1936 onwards, German soldiers needed permission to marry that was automatically given only if the bride was of 'German or allied blood'. See for details Diemut Majer, 'Fremdvölkische', I9I. 
are obsolete. Because back then a soldier merely represented a power; today he represents more: a world-view. He has to represent a superior morality. The soldier of today is no mere mercenary foot soldier (Landsknecht). ${ }^{26}$

Prohibitions were one thing, while the reality was another. In the period of the invasion and the first months of occupation, all three kinds of sexual contacts consensual, forced, and commercial - were frequent. One and a half million German men brought along with them their gendered identities and their emotional and sexual needs. So, with the invasion, the need for sexual services increased. From numerous small, medium and large towns, from all regions of conquered Poland, in the first phase of the occupation one can find evidence of Germans visiting (as yet) unregistered prostitutes. At the beginning of the occupation, illegal prostitution flourished - some examples from cities should suffice here. Condoms covered the main green space of Cracow, the Planty, in the early days of the occupation, ${ }^{27}$ because soldiers and prostitutes met there. In autumn I939, German men consorted so openly with prostitutes in Warsaw that a Pole commented: 'It was always said that we would get things back in order when the Germans came. But now, I see that the whores are having success with the German soldiers. ${ }^{28}$

Consensual relations without a direct financial component were also frequent. ${ }^{29}$ Early witnesses of the first weeks and months talk about a phenomenon that was not particularly uncommon. The German soldier Konrad Jarausch observed people making contact in Krośniewice near Lódź on market day in early October I939. Soldiers shouted out comments to amuse the women, who (according to Jarausch) 'did not take the racial divide (völkischen Gegensatz) too seriously and smiled back happily'. ${ }^{30}$ In another place he describes in a letter to his wife that the Polish girls were not very reserved, and he talks about the Polish women as girlfriends of his comrades, which bothered him since he took such things - along with drunkenness - as a sign of moral decay. ${ }^{31}$ The Wehrmacht officer Wilm Hosenfeld wrote to his wife in October from Pabianice near Łódź:

You know me and how much I am at the mercy of the eternal feminine, how my insides are in a knot in the presence of a woman. There surely would be plenty of chances to start philandering here, but I won't betray my sweet, faithful darling. ${ }^{32}$

\footnotetext{
${ }^{26}$ See Archiwum Państwowe Poznań (hereafter APP): 465/28I, p. 22, explanatory leaflet 'Wir fordern völkische Haltung', I94I.

${ }^{27}$ See Maria Odyniec, 'Kamienica przy Smoleńsk: Zapiski I939-40', Znak, 9 (I989), 68-74, here 74 . I thank Dr. Anna Czocher from IPN Kraków for this reference.

${ }^{28}$ BArch B: R I9/334, p. I5, Headquarter Warsaw to Police Regiment Warsaw from I3.II.I939.

${ }^{29}$ See for the following argumentation in more detail Röger, 'Sexual Contact'.

${ }^{30}$ Letter from Konrad Jarausch to his wife [probably 3 Oct. I939], in Konrad H. Jarausch and Klaus J. Arnold, eds, 'Das stille Sterben . . .': Feldpostbriefe von Konrad Jarausch aus Polen und Russland 1939-1942 (Paderborn: Schöningh, 2008), II2.

${ }^{31}$ Letter from Konrad Jarausch to his wife, 29 Nov. 1939, in Jarausch and Arnold, Sterben, I42.

${ }^{32}$ Letter from Wilm Hosenfeld to his wife, 23 Oct. 1939, in Militärgeschichtliches Forschungsamt, ed., Wilm Hosenfeld, 'Ich versuche jeden zu retten': Das Leben eines deutschen Offiziers in Briefen und Tagebüchern (Munich: Deutsche Verlagsanstalt, 2004), 276.
} 
However, he stresses that other men in that setting were not so steadfast. ${ }^{33}$ Reporting on comrades' sexual misbehaviour while emphasising one's faithfulness is a quite typical pattern of communication with the correspondents at home mostly family, wives, girlfriends. ${ }^{34}$ In Dębica and Cracow, German members of the military caroused with Polish women, ${ }^{35}$ and in other cities they danced with one another or talked openly on the street. For this reason, the commander of the police in Warthegau warned repeatedly in November I939:

It is once again called to your attention that an obligatory distance is to be maintained from the Polish population. Conversations with Polish women on the street and in taverns are forbidden. ${ }^{36}$

There were numerous examples in the first weeks of the occupation that involved rank-and-file soldiers as well as members of the SS and police. For example: around Christmas I939, shortly after the invasion, a member of the Sicherheitsdienst (Security Service), Georg D., along with his comrades got to know several Polish women in the FF café in Warsaw. Afterwards they went to the room of one of the women where they spent the night together. D. and one of the women got together several times after that until this occupier began a relationship with a supposedly ethnic German woman (who was in fact Polish). ${ }^{37}$

Studies about intimate fraternisation in other countries in Europe emphasize a curiosity about the strangers as one motive of the local women, which would include interest in the visually different physical appearances of the soldiers. At the beginning of the period of occupation, these were always the strongest motives. ${ }^{38}$ For Poland, the writer Karol Irzykowski explained in his diary that the large number of German-Polish couples at the beginning of the war was due to a fascination with the exotic: 'The German is with regard to the erotic something like a negro [murzyn, M.R], only green, not black'. ${ }^{39}$ What was exotic for the Poles was, of course, not a German as such, since there were diverse German-Polish contacts before the war, but rather the men in primarily greenish uniform of Wehrmacht. Although in fact the occupation began much more brutally in Poland than in other countries, ${ }^{40}$ and

${ }^{33}$ Forschungsamt, Hosenfeld, 289.

${ }^{34}$ This is one of the results of the research on army postal service. For a recent survey on emotional communication patterns, see Hester Vaizey, Surviving Hitler's war: Family life in Germany, 1939-1948 (Houndmills, Basingstoke: Palgrave Macmillan, 20Iо).

${ }^{35}$ See Bundesarchiv Militärarchiv (hereafter BArch MA): $\mathrm{RH} 53-23 / \mathrm{I} 5$, Report of the Grenzabschnittkommando South to the Oberkommando Ost from 5.I2.I939.

${ }^{36}$ United States Holocaust Memorial Museum (hereafter USHMM): RG-I5.OI2M/r.oI, pp. 22-3, Commander of the Order Police to the Governor of Posen, Daily Directive from Io.II.I939.

${ }^{37}$ See Archiwum Institut Pamięci Narodowej (hereafter AIPN): GK I06/8I, diverse interrogation protocols.

${ }^{38}$ For an overview see Anette Warring, 'Intimate and Sexual Relations', in Robert Gildea, Olivier Wieviorka and Anette Warring, eds, Surviving Hitler and Mussolini: Daily Life in Occupied Europe (Oxford: Berg, 2006), 88-I28.

${ }^{39}$ Karol Irzykowski, 1916-1944: Dziennik, Vol. 2 (Cracow: Wydawn. Literackie, 200I), 399, diary entry from 22. IO.I939. I thank Dr. Ewa Wółkiewicz, PAN Warsaw, for pointing me to this diary.

${ }^{40}$ Bombings also hit civilians and the Einsatzgruppen wrought havoc on the intelligentsia and the Jewish population. See Klaus-Michael Mallmann, Jochen Böhler and Jürgen Matthäus, Einsatzgruppen in Polen: Darstellung und Dokumentation (Darmstadt: WBG, 2008). 
much of Polish society was patriotic, one should keep in mind the differing attitudes towards Germans among people of different classes or circumstances. ${ }^{41}$ As far as the image of Polish women among German men is concerned, it drifted between the prejudice of anti-Slavism and a focus on the fabled beauty of the Polish woman. ${ }^{42}$

With the increasing length of the occupation, reports on intimate relations did not disappear, but no longer came at the rate of the first weeks of the occupation. There were several reasons for this. Firstly, the number of German men in the country was decreasing. It is indeed difficult to be precise about the total number, yet it is estimated that there were around 400,000 soldiers deployed in the annexed territories in the west and there were about a half a million in the Generalgouvernement. In addition, the GG had nearly 60,000 police and SS personnel, while the annexed territories had around 30,000 policemen. Half of these soldiers were stationed for fairly long periods of time in Poland, writes Czesław Madajczyk. ${ }^{43}$ In general, the rank and file stayed for shorter terms, while officers and SS-functionaries often spent years in Poland. In addition to the military personnel, civilian occupiers also came into the divided country, filling positions in public administration and business life.

A second reason for the reduction in reports was the increased pressure put on the occupiers and the local inhabitants by the German occupation authorities. While the prohibition of contact was indeed formally in force from the beginning of the occupation, in those first months the military and civilian occupation officials had different priorities other than regulating sex lives. Moreover, the pressure put on Polish women by the rest of Polish society increased, ${ }^{44}$ accompanied as it was with an expanding awareness of the brutality of the Germans.

If we take an integrated perspective on the sexual behaviour of German soldiers, one should mention that sexual violence also occurred during the period of the invasion. Many of the early cases were group rapes, although there is also evidence of rapes by individual soldiers, police officers, or members of the SS. ${ }^{45}$ Various previous studies have pointed to the cohesive function that group rapes have in armies and battle units. In situations of invasion and occupation, this kind of collective gendered crime serves as a form of male bonding. ${ }^{46}$

${ }^{41}$ For the different attitudes towards Germans, see Tomasz Szarota, 'Niemcy w oczach Polaków podczas II wojny światowej', Dzieje Najnowsze, X, 2 (I978), I43-75.

${ }^{42}$ For a more detailed analysis of German men's attitude see Röger, 'Sexual Contact'.

${ }^{43}$ See Madajczyk, Okkupationspolitik, 239-40: because of the continuous fluctuations, the given numbers are to be understood as approximations.

${ }^{44}$ For punishments by Polish society see Röger, 'Sexual Contact'.

${ }^{45}$ See for already known incidents Alexander B. Rossino, 'Destructive Impulses: German Soldiers and the Conquest of Poland', Holocaust and Genocide Studies, II, 3 (I997), 35I-65; Böhler, Auftakt, especially ch. 6.

${ }^{46}$ See Regina Mühlhäuser und Insa Eschebach, 'Sexuelle Gewalt im Krieg und Sex-Zwangsarbeit in NS-Konzentrationslagern: Deutungen, Darstellungen, Begriffe', in Insa Eschebach und Regina Mühlhäuser, eds, Krieg und Geschlecht: Sexuelle Gewalt im Krieg und Sex-Zwangsarbeit in NSKonzentrationslagern (Berlin: Metropol, 2008), II-32, here 38, and Gaby Zipfel, 'Ausnahmezustand Krieg? Anmerkungen zu soldatischer Männlichkeit, sexueller Gewalt und militärischer Einhegung', in Insa Eschebach and Regina Mühlhäuser, eds, Krieg und Geschlecht: Sexuelle Gewalt im Krieg und Sex-Zwangsarbeit in NS-Konzentrationslagern (Berlin: Metropol, 2008), 55-74, especially $62 \mathrm{ff.}$ 
Officially, from the German perspective, the war on Poland ended on 6 October I939. That was when the last Polish troops surrendered. The invasion, including incursions affecting the civilian population, lasted several more weeks, as one can see from a number of examples. Cracow, for example, was taken by the Germans on 6 September I939, but the local military commander was only able to state in the middle of November that they were slowly gaining control. ${ }^{47}$ Some of the continuing transgressions were sexual assaults. Military Police investigated cases of sexual violence, and rapes were judged in summary courts martial. If one relies mainly on the sources of the police and courts, it seems as if every perpetrator was prosecuted. But post-war statements - either in oral history interviews with survivors or in testimonies to post-war courts - reveal a broad awareness of unpunished rapes in the period of the invasion. ${ }^{48}$

Was the German army leadership facing a common problem in these efforts to control sexual assault? It is the loss of discipline, which is one of the things expressed in sexual violence, which challenges many armies during invasions. Or to phrase it another way: was there a unique dimension to the sexualised violence during the German invasion? One hypothesis is the anti-Semitic context of the offences. The Einsatzgruppen forced both Jewish men and Jewish women to undress and then body-searched women in order to look for valuables. These units, but also the Wehrmacht, humiliated Jewish men by cutting their peyots, the sidelocks worn by orthodox believers, and raping their women and daughters. Sexualised violence was clearly used here as an act of humiliation. While most evidence outside of the court and police materials points to individual deeds, an account from Jarausch raises an issue. At his battalion stationed in November 1939 in Zgierz near Łódź, Jewish women were forced to clean the barracks - and fell victim to assaults:

Things are perfectly clean around here. Jewish girls and women were made to scour the barracks and clean the windows. Among them were surely many who come from wealthy families. My comrades behaved poorly. Yet at a practical level the racial laws here might help to protect the Jewish women. With the female Poles it is extremely bad here $^{49}$

Sexual assaults seemed to have been accepted by Jarausch's unit leaders. It was especially Jewish women and girls who by 1939 were left with almost no right to personal (that is, sexual and bodily) integrity. The further loss of rights for the Jews of Poland led to a high degree of sexual violence against Jews over the course of the occupation.

\footnotetext{
${ }^{47}$ See BArch B: RH 53-23/I4b, p. I28, report of military commander in Krakow IIa, Grenzabschnittskommando Süd, vom I9.II.I939.

${ }^{48}$ See, for example, BArch B I62/3529, p. 95 f., interrogation protocol of Ewald L., former member of ethnic German Selbstschutz from 23.2.1963.

${ }^{49}$ Letter from Konrad Jarausch to his wife from is Nov. 1939, Zgierz, in Jarausch and Arnold, Sterben, I $35 \mathrm{f}$.
} 


\section{Intimate relationships and attempts to regulate them during the occupation}

Over the course of the occupation, all kinds of contacts continued. Even though the occupying authorities employed a brothel system to meet the occupiers' demands for sexual services, ${ }^{50}$ intimate contact with Polish women outside brothels continued to be forbidden. This was true for illegal prostitution, characterised by sex for financial gain, as well as for all forms of consensual relations that often, but not necessarily, included some personal gain for the woman but in most cases not simply a payment. For the majority of Polish society, no difference was perceived between prostitutes and women consorting with Germans. A well-known joke ran: Two men meet, and one asks the other:

'Waclaw, do you know what you call a woman who goes out with a German?'

'No, what?'

'A Philatelistin.' [A woman who collects stamps - Briefmarken in German, M.R.] '?'

'She collects Reichsmarks. ${ }^{51}$

Certainly many of the relationships during the occupation must be judged as survival prostitution or sexual bartering. ${ }^{52}$ The bartered goods for each GermanPolish couple could be different. Possibly for the occupier it was not always just physical, but also for the human warmth or the social network behind the woman (in those cases where the occupier had become integrated into her family), giving him a slice of normality in wartime. Then, on the other hand, for the the people of the occupied country it might be luxury items, money, foodstuffs, and protection. In addition, as the intimacy grew deeper, occupiers got 'their' women better jobs or got them included on the Deutsche Volksliste (German Ethnic Classification List, or DVL), which gained them privileges. The local leader of the ethnic German community in Pruszkow was upset about the 'short-cuts through proper channels' that a woman in the town had been able to use to get Volksdeutsche status:

She got to know a German sergeant who arranged for her to receive an identification card without our knowledge. She had got the identification card 3 months earlier. How, I do not know. I would have had to deny her because of her anti-German behaviour. ${ }^{53}$

The motives of the women were mixed: for example, personal affection and political affinity could go hand in hand, or there could also be the mixture of a woman's desire for power and the feeling of being in love. How closely a relationship

${ }^{50}$ The prostitution system of German occupiers in the Polish territories will be part of my planned monograph.

${ }^{51}$ Grzegorz Załęski, Satyra $w$ konspiracji, 1939-1944, 3rd edn (Warsaw: LTW, 2010), 246. My thanks to Professor Tomasz Szarota for this reference.

${ }^{52}$ See my argumentation and examples in Maren Röger, '(Nie-) codzienność podczas niemieckiej okupacji we Francji, w Belgii i w Polsce: Prostytucja, stosunki intymne i dzieci wojny', in Waldemar Grabowski, ed., Okupowana Europa: Podobieństwa i różnice (Warsaw: IPN, 20I4). For more detail on this argumentation about motives see Röger, 'Sexual Contact'.

${ }^{53}$ See Archiwum Państwowe Warszawa (hereafter APW): 486/2II, Vol. a., p. 388, Letter of the leader of the local 'ethnic German' community from 22.07.I94I. 
could be tied up with material needs is clearly seen in the history of the Warsaw Jew Emilia H. She rejected in early I940 the advances of a corporal, but then later that year she ran into him again. In her interrogation she said:

In the intervening time, my furniture had been taken away and I was forced to sell my valuables. That was to say I had suddenly become poor. I told this to B. . . and he had pity on me . . From then on, a love affair began and went on for 8 months. With B. I again and again had sexual intercourse. We intended to get married when the war was over. B. does not know that I am a Jew. ${ }^{54}$

This example shows that the boundary lines between survival prostitution, a consensual relationship, and sexual coercion were fluid. All barter exchanges took place in a clearly structured power setting which assured the male occupier material superiority and legal privileges - Mühlhäuser stresses that this situation obtained in the Soviet Union, and it is also valid for the occupied Polish territories. ${ }^{55}$ German men were clearly aware of their privileged status in occupied Poland as seen in their material advantages in comparison with the Polish non-Jewish and to the Polish Jewish population. Moreover, they were also aware of their legally privileged position: they were the ruling class, the Herrenmenschen. ${ }^{56}$

What one sees generally is that the longer-lasting relationships with Polish women are documented primarily in the ranks of the police and the SS. There are several reasons for this: firstly, these men stayed longer in the occupied Polish territories a significant difference from the simple infantryman. Members of the regular army were by and large in the country for a short period, so for that reason violations of the prohibition of contact as a rule were briefer, became less well-known, and since the men were by then already somewhere else - tracking them down was hardly worthwhile. Members of the police and the SS, in comparison, lived stable lives in the occupied territories. In some cases, occupiers and Polish women lived in marriagelike relationships; the Ostehe (eastern marriage), as the Reichssicherheitshauptamt called this type of relationship, was a frequent phenomenon. ${ }^{57}$

A second reason was that it was these men, above all, who could offer material advantages. In the occupied east, they were rich with booty that they could send back to their families in Germany, ${ }^{58}$ or even give to the women around them. German men could offer their Polish girlfriends luxury goods that had been confiscated from Jewish and non-Jewish Poles. Felix O. drove from Plöhnen to go 'shopping' with his Polish girlfriend in Litzmannstadt, one of the Polish cities with the largest ghettos. ${ }^{59}$ A resistance song that was widespread during the occupation mentions specifically the source of the luxury goods, namely, the ghetto. One of the verses (rhyming in the original Polish) says:

\footnotetext{
${ }^{54}$ APW: 482/92, B1. 4, Statement of Emilia H. from June I94O.

${ }^{55}$ See Mühlhäuser, Eroberungen.

${ }^{56}$ For a convincing analysis of the behaviour see Roth, Herrenmenschen.

${ }^{57}$ Concerning Ostehe, see a report of the RSHA from occupied Poland, I943, quoted by Roth, Herrenmenschen, 38 .

${ }^{58}$ See the more pointed thesis about the connection in Götz Aly, Hitler's Beneficiaries: Plunder, Racial War, and the Nazi Welfare State (New York: Henry Holt and Company, 2005).

${ }^{59}$ APW: 644/58, Statement of the Housekeeper from Sept. I94I.
} 
There goes a proud young girl, hand in hand with the occupier, with her dress from the ghetto. 'Aren't you ashamed, father, for having such a daughter? No, you do nothing, for the daughter is just like the father. You became an ethnic German'60

Thirdly, it seems obvious that the more frequent presence in the documentation referring to liaisons of SS men and police with Polish women can be attributed to the harsher prosecution of such relationships than those received by soldiers. Clearly, if regular German soldiers were under the racist regulations of the Nazi ideal, including the prohibition of contact with Slavs (referred to as sub-humans), it was the members of the SS who were supposed to represent the racial elite of the new Germany, which is why another level of zeal for persecuting non-Germans and keeping one's distance from them was expected to triumph.

But a closer look reveals a more complicated picture, since it was apparent that within the SS apparatus itself there were attitudes opposing this strict view, as seen in repeated attempts to overturn the prohibition of contact with Polish women. The clearest example of this came to light at a meeting of judges on 7 May I943. Both the chief judge of the SS and police court and the central office saw it as 'pressing' to make a change since the reports sounded so bad. In Cracow the situation was untenable.

A few clumsy ones were caught and punished. For most of them, they were simpletons who violated the order for the first time simply out of sexual need, then were caught and punished. The smart ones who regularly violated the order or had steady relationships were not found out and as a result were not punished. ${ }^{61}$

And the men in Warsaw were even told that the Reichsfuhrer-SS had changed his mind. The one caution was that from these supposedly approved relationships, 'no ramifications were allowed to ensue'. In Warsaw, 'almost every leader [had] his Polish or non-German relationship'. And for those who stood higher in the hierarchy, hardly anything at all happened to them, which was why the men understood the prohibition of contact to be nominal. Günther Reinecke, chief judge of the superior court for the SS and police, summarised the statements pointedly as follows: it is 'clear that the order is only on paper and must be dropped'. ${ }^{6}$

In the temporary local communities in which the occupiers lived, a permanent negotiation process was ongoing as to which behaviours were acceptable. This was true not only for criminal offences and for the ways of dealing with the Jewish and Polish civilian populations, but also for the arranging of intimate life. In the process, a consensus could take shape that was at odds with the ideological guidelines. What is striking is that after taking up an investigation against an occupier (a Reich German) for intimate relations with a Polish woman, these inquiries in most cases ended up being expanded to include more persons. Even if not every man in a SS or

\footnotetext{
${ }^{60}$ See Załęski, Satyra $w$ Konspiracji, 332. In the original, the text says: 'Idzie sobie panna. Ze szwabem pod rękę. Bardzo z tego dumna, Z "getta” ma sukienkę. Za taką córeczkę. Jak ci nie wstyd, ojcze? Nie wstyd, bo jak córka, Stałeś się folksdojczem’

${ }^{61}$ Mühlhäuser, Eroberungen.

${ }^{62}$ Ibid.
} 
police office was violating the prohibition of contact, many of them were. Sexual relations with local women were interpreted as a right of the occupiers in the sense of compensation for the hardships of being in the east. These findings call to mind Thomas Kühne's argument with regard to the Wehrmacht soldiers: cohesiveness was a question of norm violation, often expressed in sexual adventures. ${ }^{63}$ Nonetheless, there were still enough members of the SS and police who were so strictly against any kind of consorting with local women that they would denounce their fellows officially. And now and then German women auxiliaries also denounced others. ${ }^{64}$

How were the men punished? Looked at logically, the Umgangsverbot should first of all have led to uniform punishments for non-compliance. But for the annexed regions, a firm directive was issued from the Reichssicherheitshauptamt to let punishments remain variable. 'If a disciplinary action is necessary in a case, the punishments must be completely differentiated. ${ }^{65}$ So the punishment practices in the annexed regions were to be heterogeneous and in fact they were. For men who were in service to the German state, they were threatened with the loss of their jobs. Clerks were to be dishonourably discharged, with loss of pension, and civil service employees were to be summarily fired. ${ }^{66}$ One example is Horst R., who between I94I and March I942 had sexual contact with several Polish women and was fired (along with his coworker) from state service in line with the decree of the Reich Ministry of the Interior. Their release from duty was to be read in front of the whole entourage of the state police administration in Posen 'so that this could serve as a warning to the collective staff, because again and again complaints are being made about the interactions of Germans with Polish women'. ${ }^{67}$ This is only one example, but the spectrum of punishments for Reich German men could range from being reprimanded, arrested, taken into preventive custody, designated for deployment to the front, or being sent to a concentration camp as the most extreme form.

For the Polish women, punishments were differentiated, too. In general, the punishment for them was not the same as for Polish men who were slave workers and who consorted with German women in the Altreich. These latter were often executed or sent to a concentration camp. ${ }^{68}$ Polish women, according to the logic of National Socialist gender ideology, could not 'pollute' German men to the same

${ }^{63}$ See Thomas Kühne, Kameradschaft: Die Soldaten des nationalsozialistischen Krieges und das 20. Jahrhundert (Göttingen: Vandenhoeck and Ruprecht, 2006), I20.

${ }^{64}$ For examples like this in France see Franka Maubach, Die Stellung halten: Kriegserfahrungen und Lebensgeschichten von Wehrmachtshelferinnen (Göttingen: Vandenhoeck and Ruprecht, 2009), e.g. I60.

${ }^{65}$ BArch B: NS 47/30, o.P., RSHA to Gestapo main offices in Königsberg, Tilsit, Allenstein, Zichenau, Danzig, Graudenz, Bromberg, Posen, Litzmannstadt, Hohensalza, Kattowitz, Oppeln; Berlin, 20.05.1942.

${ }^{66}$ See BArch B: R I9/3II, B1. 248 f., Decree of the RMI I2.02.I94I concerning the interaction of Officials, Employees, and Workers of the Civil Servants with persons of the Polish Volkstum having previously had Polish citizenship.

${ }^{67}$ See BArch B: R 19/253, Bl. 317, The Government of Posen to RFSS I7.4.1942.

${ }^{68}$ For an analysis of the politics towards Polish slave workers and German women see Robert Gellately, 'Political Justice, Popular Justice, and Social Outsiders in Nazi Germany: The Example of Polish Foreign Workers', in Robert Gellately and Nathan Stoltzfus, eds, Social Outsiders in Nazi Germany (Princeton, NJ: Princeton Univ. Press, 200I) 256-72, and Birthe Kundrus, 'Forbidden Company: Romantic 
extent, so punishments were on the surface more lenient: temporary imprisonment and/or registration as prostitutes. The latter could place the women into a vicious circle. Once registered, they were not able to find a job beyond sexual business, so they were turned into prostitutes even though they had not been prostitutes before. In the Warthegau, punishment was more brutal: Polish women consorting with Germans were not only registered as prostitutes, but directly forced to work in an occupier-controlled brothel. In these institutions, the women lived an existence in barracks with a complete loss of individual liberty. ${ }^{69}$

To provide a complete picture, one has to underline the fact that Polish patriots also tried to discipline women who were consorting with Germans: accusatory leaflets, moral suasions, and honour punishments (such as head shavings, or even executions in extreme cases when when treachery had been involved) were a common phenomenon at least in the GG. ${ }^{70}$

\section{Herrenmenschen: Sexual violence and its regulation}

In the annexed territories as well as in the General Government, German occupiers used their privileges to impress local women. But the line between consensual relations and sexual blackmailing was frequently thin. One example was the Jewish woman in Warsaw who agreed to enter into a relationship only after having lost the basics things needed for living. ${ }^{71}$ However, other cases also in police and court records reveal a system of sexual blackmailing used in offices and workplaces. The occupiers had power over the life and death of Polish women as well as the imprisoned members of their families. They also had power over jobs, travel permits, or other important documents. Numerous studies have pointed out the corruption among the occupiers. ${ }^{72}$ The medium of exchange was not only money, but also sex. Here the border between sexual coercion and rape was fluid. One clear pattern of sexual violence in the occupation context was sexual blackmail. There were rumours about Herbert Strickner, who was responsible for the Germanisation process (Eindeutschungen) in the Warthegau, suggesting that beautiful Polish women got faster access to the DVL and the legal advantages that came with it. One Polish woman accused him of sexual harassment during such a proceeding. ${ }^{73}$ Sexual coercion took place mainly in the workplace. Women did not want to lose their jobs, and often suffered transgressions in silence. Losing a job at the time of the German occupation was not a trivial matter, since those who were unemployed were sent to the Reich, where unknown working and living conditions awaited them.

Relationships between Germans and Foreigners, I939-I945', Journal of the History of Sexuality, II, I/2 (2002), 20I-22.

${ }^{69}$ For the system of prostitution and sexual slavery in occupied Poland see my planned monograph.

${ }^{70}$ For blame and punishment strategies by Polish patriots see Röger, 'Sexual Contact'.

${ }^{71}$ See APW: 482/92, p. 4, Statement of Emilia H. from June I94O.

${ }^{72}$ For corruption among civil occupying authorities see Roth, Herrenmenschen, 8, 28.

${ }^{73}$ See AIPN: Po 796/I52, p. I22, Statement from Herbert Strickner. 
Further, using flimsy official pretexts, the occupying forces demanded access to Polish flats and houses to perform searches and seizures. It was low-ranking officials especially who behaved in this way, according to Anna Czocher, with officials blackmailing residents for various material goods: a free lunch, alcohol, valuables, or simply money. ${ }^{74}$ In this context, occupiers also committed rapes. For example: in August 1940, a robbery and rape attempt took place in Litzmannstadt, 'by two men who created the impression of being policemen by wearing the uniform and equipment'. They claimed they were to take the girls living there to be sent to work in Germany. ${ }^{75}$ In February 1942, the authorities in Leslau searched for a serial offender using a similar tactic. ${ }^{76}$ The perpetrators used uniforms or a German badge as their insignia of authority. If a police or Gestapo uniform were seen, the investigating German officers immediately assumed that it must have been a disguise. They were convinced that the perpetrators must have been Poles or Russians. How far the assumptions could influence investigations is seen in a particularly absurd example. In the forest of Konicbor in the district of Sudauen in October I942, a murdered Polish woman was found who had apparently been killed in the course of a rape. The case was linked to the rape and murder of a young peasant woman, which had been committed a few days earlier in the same area. In none of the cases were there any witnesses or suspects. But for the criminal police it was clear: 'there are no traces of the offender, but it is probably a question of a Russian prisoner of war or a fugitive worker from Eastern Europe'. ${ }^{77}$ To search among the occupiers' community was obviously not even considered.

If we take a closer look at the sites of the rapes and molestations, they were often the places of arrest: prisons, ghettos, camps. Polish (and non-Polish) Jews especially very often fell victim to sexual violence. One explanation for what appears to be the particularly high incidence of rapes and sexual assaults in prisons, ghettos and camps lies in the nature of the historical source material. Post-war trials were about German crimes against the Jews of Europe in which, en passant, sexual violence was mentioned. Also, the huge interview collection of the Visual History Archive consists of interviews conducted with Jews who survived such crimes. A more plausible explanation, however, is not only that ghetto and camps formed the local sphere of opportunity but that they also formed the juridical sphere of opportunity, a locus in which, because of the complete annihilation of all their rights, there was a consciousness that crimes against Jews usually had no consequences.

The occupation opened up the opportunity for 'spaces of violence' ('Gelegenheitsräume der Gewalt') as Bernd Greiner has argued with regard to the Vietnam War. ${ }^{78}$ Although it is impossible to provide absolute numbers for the sexual assaults committed by Germans in the occupied Polish territories, as a rule the number

\footnotetext{
${ }^{74}$ See Czocher, W Okupowanym Krakowie, I55.

${ }^{75}$ USHMM: RG-I5.OI3M/r.oI, p. I2 ff., Report of Criminal Police in Litzmannstadt from 2I.08. I940.

${ }^{76}$ USHMM: RG-I5.0I3M/r.03, p. 35, Report of Criminal Police in Hohensalza from Io.03.I942.

${ }^{77}$ APW, Dependencie Pułtusk: I206/24, p. I6, Criminal Police in Tilsit to Reich Criminal Police Department from I3.IO.I942.

${ }^{78}$ See Bernd Greiner, Krieg ohne Fronten: Die USA in Vietnam (Hamburg: Hamburger Ed., 2007), 25.
} 
of crimes never reported is quite high and it is obvious from the sources that sexual violence was not an exception to this pattern. The occupation of Poland in general was marked by a very high level of everyday violence against civilians. ${ }^{79}$ Sexual assault was one of the different forms of this violence, along with looting or violent acts during arrests and interrogations. Prevalent among different occupier communities was the feeling of being superior, a Herrenmensch (as Markus Roth has persuasively described the psycho-social constitution of the Kreishauptleute, the civilian officials in charge of a district in the GG) ${ }^{80}$ Some of them felt a right to have Polish women, or had the impression of being beyond the law. This became clear in statements of some perpetrators to the police or before the court.

But how did the authorities react to the sexual violence? As suggested earlier, sexual violence was seen as a threat to discipline and, moreover, such incidents could damage the German reputation (which in view of the brutal occupation policies is quite cynical). Therefore, sexual violence was not encouraged (contrary to what Susan Brownmiller states in her I975 study about sexual violence in history in which she states on the basis of a few and scattered sources that the German army used sexual violence systematically as a tool in the Second World War). ${ }^{81}$ Nevertheless, neither were actions of any lasting consequence taken to prevent it. Generally, sexual violence is an offence where evidence can be flimsy. Modern criminal means such as DNA analysis were obviously not available then. Usually, the officers looked for indications of violence on the victims, and this included gynaecological examinations of any minor. The former district medical officer in Wysoka near Bromberg once examined for a court proceeding the hymen of a young Polish woman who had been raped by a member of the SS. He replaced a Polish doctor, who had not wanted to provide his opinion. One can see that with regard to sexual offences, not only were the Polish victims intimidated, but Polish doctors as well, when in service to the court. The danger was ending up in a situation of having to proffer an opinion that went against a German, against the occupier.

Since evidence is often scarce, sexual violence investigations are characterised by the simple fact that it is one person's word against another's. And the racist hierarchy in occupied Polish territories had a strong impact on how the statements were evaluated. All the authorities involved in the investigations also judged the character of the victims. An example of this can be seen in the investigation of a gang rape of two waitresses in Siedlce in the district of Warsaw. One of the victims was assessed positively as follows: 'the raped Jadwiga P. is a country girl who makes a very quiet, but decent impression. Without a doubt one can trust her testimony, which was given very objectively and accurately.' The other victim was judged negatively as a loose girl. ${ }^{82}$ Even through three German perpetrators were in fact eventually convicted, this illustrates the danger for women that even at the initial stage of the

\footnotetext{
${ }^{79}$ See, for example, the contributions to the anthology by Jochen Böhler and Stephan Lehnstaedt, eds, Gewalt und Alltag im besetzten Polen: 1939-1945 (Osnabrück: fibre-Verl., 2012).

${ }^{80}$ See Roth, Herrenmenschen.

${ }^{81}$ See Susan Brownmiller, Against Our Will: Men, Women and Rape. Vintage, I975, passim.

${ }^{82}$ See APW, Dependencie Pułtusk: I207/3696, p. 9, Final report of Gendarmerie Siedlce from 8.05.I94I.
} 
police investigation they could be judged as non-credible. In court, similar patterns were also true when credibility as a Polish woman also played an important role. Monika Flaschka argues that the sexual behaviour or the sexual reputation of the raped women was even more important for the Warthegau than ethnic affiliation:

More important than discussions of race, were assumptions about the normative behavior of women. When women acted in ways the court believed conflicted with normative gender roles, the court questioned: whether their testimony was truthful, whether they had actually been raped, and their motives for accusing soldiers of rape. ${ }^{83}$

German perpetrators were perfectly aware of the racial hierarchy and its impact on the credibility of statements. Several suspects discredited the Polish victims as being anti-German and making false claims for this reason. Further, alcohol abuse was used and sometimes accepted by the court as a strategy for a dismissal of charges. ${ }^{84}$

This should not obscure the fact that the German courts in occupied Poland gave very severe sentences to sex offenders. Overall, the penalties varied greatly, influenced by certain factors. Alcohol consumption at the time of the rape, but also in the history of the occupier was among them. Further, the level of engagement of the men in the party and the army, as well as their previous behaviour, was given importance. Whether there was a criminal record, in particular regarding sexual offences, played a role, too. The spectrum of punishments for Reich German perpetrators ranged widely - from short arrest or imprisonment for several years to being sent to the front line. The maximum penalty was death. According to Snyder, the Wehrmacht Courts imposed this penalty in only I \% of the proceedings related to sexual violence. ${ }^{85}$ Whether this is true as well for other convictions cannot be tracked due to a deficiency in sources. But it is clear that the death penalty was only for cases that attracted much public attention. In court, the reputation of Germans was defended; the occupiers thought that sex offences were very likely to be exploited by enemy propaganda. Therefore, the Special Court in Hohensalza sentenced to death two Germans who had publicly 'celebrated' their rape in a village in front of several dozen Poles. ${ }^{86}$

\section{Conclusion}

Despite all ideologically motivated efforts, it was not possible to separate the German occupiers completely from the local Polish population. The invaders had social contact with Polish families, but also intimate contact with Polish women. German women auxiliaries, however, consorted rather with their German

\footnotetext{
${ }^{83}$ See Flaschka, Race, 9I.

${ }^{84}$ My findings confirm the findings by Beck, Wehrmacht und sexuelle Gewalt, 267-72; Snyder, Sex Crimes, 219; Mühlhäuser: Eroberungen, I47, Flaschka, Race, II5, who pointed out how excuses were permitted and more lenient punishments were applied in cases of sexual violence involving drunkenness on the part of the perpetrator.

${ }^{85}$ See Snyder, Sex Crimes, IOI.

${ }^{86}$ See USHMM: RG-I5.0I4/r.02, I-I7, Judgement against Oskar S. und Karl K. of the Special Court Hohensalza from 08.02.I94I.
} 
colleagues who were numerous and more attractive in terms of their economic situation. Same-sex relations between German men and Polish men were also rarely documented.

Consensual contact between occupiers and the people of occupied Poland was a common phenomenon in the first weeks of the occupation. After the mass of soldiers returned to Germany, the occupiers increased the pressure regarding the prohibition of contact and the pressure on Polish women from Polish patriots was heightened as well. At this point sexual contact was no longer a mass phenomenon. However, the fact that warnings and regulations continued to be issued from both sides - the occupiers and Polish society - shows clearly that these were not isolated instances. What one sees generally is that in the case of the longer-lasting relationships with Polish women documented primarily in the ranks of the police and the SS, one reason was that these men had something to offer - protection, better work, and material support - to women in a population that was in grosso poverty-stricken and deprived of its rights. Such relationships were frequent and deep enough for the idea of Ostehe - eastern marriage - to be common. The occupying and Altreichbased authorities were aware of this intimate contact, and reacted with a range of punishments - from severe to lenient but a closer look at this aspect of the everyday history of the occupation reveals clearly how improvised the occupational policies were: racial ideology remained in contradiction to the realities of life in the occupied territories.

The same is true for official reactions to sexual violence by German occupiers. The sexual behaviour of some German men clearly mirrored their internalisation of the idea of being Herrenmenschen in the occupied east: they blackmailed, molested and raped local women, in complete awareness of the fact that Polish statements were easily doubted in front of the courts. Punishments oscillated between harsh reactions - especially when there was a need to protect against damaging the German reputation - and easy exoneration, following the excuses of the men about alcohol abuse. To sum up, the sexual behaviour of German occupiers in the Second World War Poland ranged from affection to bribery to violence. Contacts with local Polish women mirror power relations in regard to gender and sex in the occupied east.

\section{Politiques sexuelles et réalités sexuelles en Pologne sous l'occupation allemande pendant la Deuxième Guerre mondiale}

La politique nazie en matière de sexualité faisait partie intégrante de la politique raciale du national-socialisme, tant dans l'Altreich (l'Allemagne d'avant l'Anschluss) que dans les territoires sous occupation allemande. En Pologne occupée, les Allemands imposèrent une interdiction de contact (Umgangsverbot) avec la population polonaise autochtone, cette restriction portant sur les rapports tant sexuels que sociaux en général. Mais ce modèle de ségrégation raciale totale ne fut jamais vraiment appliqué. Cet article vise à montrer qu'il y avait en fait toutes sortes de relations sexuelles entre l'occupant et la population du pays occupé, et considère tout particulièrement les rapports consensuels et les rapports forcés (violence sexuelle) dans le contexte des politiques du national-socialisme. L'auteur se positionne, pour son étude de la Pologne sous occupation allemande, au carrefour entre l'histoire de la vie quotidienne, l'histoire de la sexualité et l'histoire du genre: ce sont là des perspectives qui n'ont encore que rarement été appliquées à cette région. 


\section{Sexualpolitik und Besatzeralltag im besetzten Polen, I939-I945}

Sexualpolitik war Kernbestandteil der NSVolkstums- und Rassenpolitik - sowohl im Altreich als auch in den besetzten Territorien. Im okkupierten Polen verhängten die deutschen Besatzer ein Umgangsverbot mit der einheimischen polnischen Bevölkerung, das gesellschaftliche, aber auch sexuelle Kontakte umfasste. Doch dieses Modell der absoluten Trennung konnte nicht umgesetzt werden. Vielmehr möchte dieser Aufsatz zeigen, dass ein breites Spektrum an sexuellen Kontakten existierte: Im Fokus stehen konsensuale Kontakte und erzwungene Kontakte, also sexuelle Gewalt, die vor dem Hintergrund der NSPolitik diskutiert werden. Der Artikel richtet damit einen alltags-, sexualitäts- und genderhistorischen Blick auf das deutsch besetzte Polen - in Bezug auf diese Region bislang selten angewandte Perspektiven. 